PROBLEMS

OF EDUCATION

IN THE $21^{\text {st }}$ CENTURY

Vol. 76 , No. 6, 2018

\author{
Durmuş Karci \\ International Burch University, Bosnia and Herzegovina \\ E-mail: dkarci44@hotmail.com \\ Cemal Özdemir \\ Suleyman Demirel University, Kazakhstan \\ E-mail: cemal.ozdemir@sdu.edu.kz \\ Nuri Balta \\ University of International Business, Kazakhstan \\ E-mail: baltanuri@gmail.com
}

\begin{abstract}
Turkish is spoken by a large number of people in a wide geographical area and teaching Turkish as a foreign language is a subject that gains importance nowadays. This research employed a quantitative survey strategy to address the issue of anxiety in learning Turkish language in and outside the classroom. Participants were 356 students of two high schools, one college and one university in Kazakhstan. Participants were given the Second Language Speaking Anxiety Scale (SLSAS), which was analyzed with: correlation to search for possible relations between anxiety, age, duration of studying Turkish, and Turkish course grades; MANOVA to assess the effect of gender and school type on students' anxiety in speaking Turkish; and an exploratory factor analysis to identify factor structure of SLSAS. Additionally, an ANOVA was carried out on a second data set with 52 students to see any differences between students' anxiety in speaking Turkish and English. The results of this research indicated that anxiety in speaking Turkish is weak and not related to students' age, gender, years studying Turkish, and Turkish course grades. In addition, no significant differences were found between students' anxiety in speaking Turkish and English. The only significant result was the relatively high anxiety of college students in the classroom. This research implies that anxiety in speaking Turkish does not differ so much from anxiety in speaking English.
\end{abstract}

Keywords: language anxiety, anxiety in speaking, Turkish as a second language.

\title{
Introduction
}

\section{Teaching Turkish as a Foreign Language}

Language is a living and natural system that enables the exchange of feelings and thoughts between people, develops in an unknown time in an unknown form, and reflects every aspect of the society in which it belongs to (Bayraktar, 2006). The need for foreign language learning (FLL) is growing in parallel with the strengthening of inter-communal relations and the progress of mass media. At the same time, today, knowing foreign languages are accepted as one of the criteria of modernity (Doğan, 2008).

Teaching and learning Turkish as a foreign language is becoming increasingly more important in parallel with Turkey's developments and initiatives in various fields. Parallel to the progresses in teaching Turkis as a foreign language, the related scientific studies are increasing (Şen \& Boylu, 2015). 
In the past several decades, the area in which Turkish is spoken has expanded. Along with this expansion, there has also been an increase in the demand for people to learn Turkish. Currently in Turkey, foreign language teaching centers at universities are at the forefront of the centers where Turkish language activities are systemically conducted for foreigners. The first center was opened in Ankara University in 1984, it was opened in 1987 at Ege University, and in 1992 at Gazi University (Şahin, 2008). In the following years, many universities have opened these centers at their own institutions and have been involved in the teaching of Turkish language activities for foreigners. In 33-year time, almost all universities opened these centers within their institutions. There are 85 Turkish education centers at universities in Turkey for teaching Turkish as a second language (Boylu \& Başar, 2016).

After the disintegration of the USSR in 1989, the Turkish government and some private enterprises opened a number of elementary and high schools in Central Asian countries (Demir, Balci, \& Akkok, 2000). At the moment, Turkish language is taught as compulsory or elective courses in about 1000 schools in the world's five continents and 120 countries (Zorlu, 2010).

Problems encountered in teaching Turkish language in universities in Kazakhstan were searched by Turumbetova (2013). The researcher evaluates the schools that continue their educational activities in Kazakhstan, as follows:

Turkish is one of the leading foreign languages in Kazakhstan. In our time, people are more curious about Turkish language compared to other languages, that is why people are trying to learn this language. Currently, growing and developing economy of Turkey in the international arena also has a huge impact on this issue. Another reason why Turkish is preferred is the fact that the language and culture of the Kazakh - Turkic nations, which originated from the same root, were the same in the past. (p. 1)

\section{An Important Factor in Learning Languages: Anxiety}

Anxiety in language learning has been extensively studied for more than fifty years (He, 2017). Anxiety is a state of alertness that manifests itself through physical, emotional, and mental changes that an individual has experienced when he or she meets a stimulus (Aiken, 1976). "Anxiety in general can be associated with threats to self-efficacy and appraisals of situations as threatening" (Pappamihiel, 2002, p. 331). Foreign language anxiety (FLA) is defined as a fear that arises when the language is used by an individual who is not fully competent in the foreign language (Gardner \& MacIntyre, 1993).

Variables regarding FLL anxiety fall into two core groups: situational variables and learner variables (Williams \& Andrade, 2008). Variables such as course level, course organization, course activities, teacher characteristics and attitudes, and social communication between learners constitute the situational ones while age, attitudes, beliefs, culture, gender, learning styles, and personality variables compose the learner variables.

Liu's (2012) findings negatively correlate the FLA with learning motivation, listening proficiency, reading proficiency, and learner autonomy. More than a few studies have revealed that FLA does have an opposing effect on learning (Daley et al., 1997; Ehrman \& Oxford, 1990; Gardner, 1985; Gardner \& MacIntyre, 1993).

Scovel (1978) thinks anxiety both in positive and negative contexts. According to him, the anxiety, which activates the student's willing to learn is positive. The anxiety that shakes the confidence of the learner, and that provokes the feeling of sadness is negative. Although there are no shortcomings in the mental sense, if the student brings himself to be overly alerted by FLL, he/she will be distracted. It is this anxiety that leads to the failure of students to use the target language in the classroom or social environment in FLL.

$\mid$\begin{tabular}{l} 
PROBLEMS \\
OF EDUCATION \\
IN THE 21 $1^{\text {st }}$ CENTURY \\
Vol. 76, No. 6, 2018 \\
\hline 817
\end{tabular} 
Durmuş KARCI, Cemal ÖZDEMIR, Nuri BALTA. In-class and out-of-class anxiety in speaking Turkish as a second language

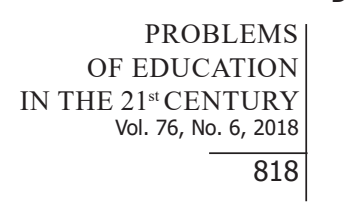

PROBLEMS

$21^{\text {st }}$ CENTURY

818

\section{Anxiety and Foreign Language Learning}

In the literature, the expression of FLA was first used by Horwitz, Horwitz, and Cope (1986). They developed a 33-item Foreign Language Classroom Anxiety Scale to measure students' anxiety in learning foreign language. In this context, FLA is explained as a set of feelings and actions peculiar to language learning classes arising from the uncertainties in the FLL process (Baş, 2013).

The primary goal of foreign language learners is to effectively and fluently speak the target language. The main aim in language teaching is to have students to gain the ability to understand and explain the target language. In this respect, unlike other skills, speaking skill is the ability that people need mostly in daily life. For this reason, in the process of acquiring speech skills in language teaching, the main goal is to enable language learners to express their emotions and thoughts accurately and fluently (Boylu \& Çangal, 2015).

Since anxiety is a factor affecting language teaching (Gardner \& Maclntyre, 1993), it is an important concept emphasized in the language teaching-learning process. Numerous studies have been carried out on the outcome of speaking anxiety, especially on students' achievement and performance (Doğan, 2008; Horwitz, Horwitz, \& Cope, 1986; İşcan, 2011; Öner \& Gedikoğlu, 2007; Yoğurtçu \& Yoğurtçu, 2013).

Studies in general have shown that students with high levels of anxiety have lower levels of achievement in second language learning. Gardner, Moorcroft, and MacIntyre (1987) aimed to find the association between levels of achievement and different levels of anxiety. They found that anxiety was a barrier to the student's success. According to MacIntrye and Gardner (1991), when compared to other academic areas, intense anxiety in foreign language classes negatively affects the language learning process and the success of students. Students who meet a new language environment feel themselves in a completely different environment, and this feeling leads to anxiety in language learning. The anxiety slows the learner's language learning process. This suggests a negative correlation between FLA and language achievement (Horwitz, 2001).

The phenomenon expressed as language anxiety has a remarkable feature in foreign language teaching research (Dörnyei, 2005). Particularly in the process of second language acquisition, individual differences, motivation, language aptitude and linguistic performance (Gardner, 1985; Liu \& Cheng, 2014; MacIntyre, MacKinnon, \& Clément, 2009) are the most important variables that determine the success.

There are two different types of anxiety; the trait anxiety is about the structural characteristics of the individuals, and the state anxiety is about the experiences in the social and physical environments (Cattell \& Scheier, 1960; Scovel, 1978; Spielberger, 1966). In addition, there is also a third category, situational anxiety, which is about the anxiety that the individuals may encounter in different conditions.

Scovel (1991) suggested a distinction between facilitating and preventive anxiety after researching many studies related to anxiety and achievement relationship. While facilitator anxiety leads to struggle in new learning environments, preventive anxiety causes the individual to adopt evasive behavior in new learning environments. For aforementioned reasons, to be able to understand if the anxiety is positive or negative, first of all the level of anxiety should be determined (Şen \& Boylu, 2015).

FLA is distinguished from general anxiety because it is closely related to the beliefs, attitudes and perceptions of the individuals in language education (Horwitz, Horwitz, \& Cope, 1986). Language anxiety is divided into three groups: communication anxiety, test anxiety and fear of negative evaluation. Communication anxiety is experienced by individuals who have mature opinions and thoughts, but who have not got developed communication skills on the target language. The test anxiety that arises in the process of academic evaluation is defined as 
the fear of failing exams. Finally, the fear of negative evaluation is a fear of foreign language learners who are not successful in making a proper social impression (Horwitz \& Young, 1991).

It has been determined that the failure of students to speak leads to an increase in the speech anxiety over time (Huang, 1994). Speech anxiety may reveal itself physically as sadness, anger, fear or rapid heartbeat and sweating. Speech anxiety can be due to mental, physiological, emotional, and inherited-biological reasons (Özkan \& Kınay, 2105). Speech anxiety is a common fear (Breakey, 2005). Approximately $14 \%$ of people in a community are faced with speech anxiety. For some people, speaking at stage is a phobia, and they prefer to stay away from such situations (Ayres \& Hopf, 1993).

MacIntyre and Gardner (1995) reported that speech practices increased the anxiety because during the conversation, people who learn foreign languages had to communicate with other people. Williams and Andrade (2008) argue that an individual who learns a foreign language can easily come to disappointment when he or she tries to express himself in front of others, and for some reasons does not achieve it. In the next step, communication becomes alarming and worrying for that person. This causes the person to experience anxiety intrinsically. According to Pong (2010), the attempt to use the language in accordance with foreign language rules causes individuals to feel themselves incapable about correct pronunciation, which creates additional anxiety among students. Gregersen and Horwitz (2002) suggest perfectionist students "that the classroom is not merely for demonstrating knowledge and skill, but also for gaining it, and that errors are a normal and acceptable part of everyone's language learning experience" (p.570).

The effect of anxiety on the foreign language is sometimes beneficial and sometimes harmful, and there is no consensus on this issue (Aydın \& Zengin, 2008).

\section{Anxiety in Learning Turkish as a Second Language}

Studies about anxiety in learning foreign languages are mainly related to learning English; however, research regarding anxiety in learning Turkish is really limited (Aydın \& Zengin, 2008).

Şen (2017) made a research to find the level of language anxiety of the Turkish language teacher candidates and to determine the level of this anxiety with respect to gender and grade. He found that the general anxiety levels of the students were weak. A similar research by Mert (2015) also revealed similar weak anxiety. Şen also stated that the speech anxieties of Turkish teacher candidates participating in the research did not differ according to the gender but found that the speech anxiety levels differed according to the grades. In some other studies on the language anxieties of Turkish teacher candidates, it was found that gender has no effect on speech anxiety (Baki \& Karakus, 2015; Karakuş, 2015).

In the research conducted by Batumlu (2006), it was shown that the level of anxiety of the students during learning did not change according to gender; but it was understood that there was a negative relationship between FLA and achievement both in male and female students. In the research conducted by Sevim (2014), it was seen that male and female students had the same amount of anxiety in speaking Turkish.

According to research results of Sallabas (2012), the gender of the students did not make a significant difference on the anxiety in speaking Turkish. This result also overlaps with the research done by Doğan (2008), Boylu and Çangal (2015), and Melanlığlu and Demir (2013). In this context, it can be said that gender has no effect on speech anxiety of learners of Turkish as a foreign language.

The degree of anxiety of students has been found not to vary according to the school type, major, grade, and whether they know another language. It is noteworthy that the average degree of anxiety of students who do not speak another language other than Turkish is higher than the average level of anxiety of students who also speak in another foreign language (Sevim, 
Durmuş KARCI, Cemal ÖZDEMIR, Nuri BALTA. In-class and out-of-class anxiety in speaking Turkish as a second language

PROBLEMS

OF EDUCATION

IN THE $21^{\text {st }}$ CENTURY

Vol. 76, No. 6, 2018

2014). In another research, Sevim (2012) found that anxiety did not differ according to major. Research by Şen and Boylu (2015), showed that there was no statistically significant difference between anxiety in speaking Turkish and the variables: age, gender, education level, Turkish language level, frequency of watching Turkish TV channels, and frequency of listening Turkish music.

Most research related to language learning is about classroom-based anxiety (Woodrow, 2006). Distinctively, this research handles second language anxiety from both within the classroom and outside the classroom perspective. The anxiety in learning a second language has been searched for many languages. However, studies concerning anxiety in learning Turkish as a second language are limited. This research aimed to determine the anxiety level of students in learning Turkish as a foreign language, and whether the in-class and out-of-class anxiety differs according to various variables. Depending on the literature review, following research questions guided this research:

- Is there a relation between the course grade, the number of years of learning Turkish and the anxiety in speaking Turkish?

- Do students' anxiety in speaking Turkish differ across students' gender and type of school?

- $\quad$ Do students' anxiety in speaking Turkish differ across in-class and out-of-class communication?

- Is there a difference between Turkish and English language anxieties?

- What is the observed factor structure of SLSAS found from exploratory factor analysis?

\section{Research Methodology}

\section{General Background}

This quantitative research surveyed a sample of Kazakh students from four high schools about their level of in-class and out-of-class anxiety in speaking Turkish. An instrument comprising 12 slightly modified items from the SLSAS (Woodrow, 2008) was used to gather data, which were collected at the end of the spring semester of 2017-2018 academic year.

\section{Participants}

There were two groups of participants in this research. The first group was 354 volunteer students (110 females and 244 males) at four schools in Kazakhstan with an age range of 12-20, and an average age of $15.40(S D=2.23)$. The number of participants from gender and school groups with their percentages are displayed in Table 1.

Table 1. Gender and schools of the participants.

\begin{tabular}{llll}
\hline Variable & Category & $\boldsymbol{f}$ & $\%$ \\
\hline \multirow{2}{*}{ Gender } & Female & 110 & 30.9 \\
& Male & 244 & 68.5 \\
& BILIM-Innovation High School for Boys & 116 & 32.6 \\
\multirow{3}{*}{ School } & BILIM-Innovation High School for Girls & 75 & 21.1 \\
& Suleyman Demirel College & 75 & 21.1 \\
& Suleyman Demirel University & 88 & 24.7 \\
\hline
\end{tabular}


The second group was 52 volunteer students from BILIM-Innovation High School for Boys (18), BILIM-Innovation High School for Girls (12), and Suleyman Demirel College (22). The data collected from this group was used to compare students' anxiety in speaking Turkish and in English. All students from both groups speak Kazakh and Russian, and they also speak Turkish and English at the upper intermediate level.

BILIM-Innovation High School for Boys and BILIM-Innovation High School for Girls: These two schools are implementing an educational system called gymnasium. While some of the courses such as physics, mathematics, biology, chemistry, and computer are taught in English, and except Russian, and Russian Literature the rest of the courses are taught in Kazakh. There are about 400 students in each of these schools and each year approximately 75 students are enrolled. Students are mostly from middle and upper socioeconomic status. Students are admitted from the $7^{\text {th }}$ grade and the schools last for five years. There are weekly six hours of English, and four hours of Turkish in the $7^{\text {th }}$ and $8^{\text {th }}$ classes and two hours of Turkish in the $9^{\text {th }}, 10^{\text {th }}$ and $11^{\text {th }}$ classes. Graduates from these schools usually prefer universities outside Kazakhstan such as China, Korea, USA, UK, and Singapore. Since they are state schools, the state meets all expenses of the students except food. Parents are only charged to pay for lunch.

Suleyman Demirel College: This is a private college which has courses such as computer programming, elementary school teaching, and finance. Courses such as physics, mathematics, biology, chemistry, and computer are taught in English, and regular Kazakhstani curriculum is implemented for the rest of the courses. There are approximately 350 students and each year about 120 students from middle socioeconomic status are registered. The College accepts students from $9^{\text {th }}$ class, and education lasts for four years. There are weekly six hours of English, and four hours of Turkish in the $9^{\text {th }}$ class and two hours of Turkish in the $10^{\text {th }}, 11^{\text {th }}$ and $12^{\text {th }}$ classes. Since the College is private, the parents pay all the costs of the students.

Suleyman Demirel University: University students who participated in this research were from a private university in Almaty, Kazakhstan. The population of the students in the university was about 3500. Each year approximately 1200 students from middle socioeconomic status are enrolled to this university. About $90 \%$ of these students have a governmental scholarship. Students are accepted after finishing the $11^{\text {th }}$ class at high school. There are four faculties and 21 departments in this university. The education language is generally English. Turkish language is mandatory for the first two years of education in this university. There are weekly three hours of Turkish course in the first year and two hours in the second year.

\section{Instrument}

For measuring the students' anxiety in speaking Turkish, the second language speaking anxiety scale (SLSAS) was employed. The SLSAS was developed by Woodrow (2008) and it was adapted to this research (permission was taken from Woodrow by email). In adapting the SLSAS all "English" words were replaced with "Turkish". For instance, the first item (The teacher asks me a question in English in class) was changed to "The teacher asks me a question in Turkish in class". Moreover, since $10^{\text {th }}$ and the $11^{\text {th }}$ items were not proper to the sample of this research, they were slightly amended too. For example, the $11^{\text {th }}$ item (Asking for advice in English from a lecturer/supervisor in my intended university faculty of study) was changed it to "Asking for advice in Turkish from a teacher in my school."

Since the education language in all schools of the participants is English, and since SLSAS's items are expressed in simple words, it was not translated. However, for validity four students (two girls and two boys) read and supplied their responses while thinking aloud. This observation detected no misunderstanding in SLSAS items.

The SLSAS items were prepared in the form of statements that one could not be anxious at all or be extremely anxious on a scale of 1 (not at all anxious) to 5 (extremely anxious) with 3 
Durmuş KARCI, Cemal ÖZDEMIR, Nuri BALTA. In-class and out-of-class anxiety in speaking Turkish as a second language

\begin{abstract}
PROBLEMS
OF EDUCATION

IN THE $21^{\text {st }}$ CENTURY

Vol. 76, No. 6, 2018

822 signifying a moderately anxious response. This means that the lower the score, the less anxious is the condition. The maximum score that could be obtained from SLSAS is 5 .

The instrument has two levels: in-class language anxiety, and out-of-class language anxiety. Woodrow calculated the reliability for in-class anxiety as .89 and for out-of-class .87 and for the combined scales .94. Similarly, in this research, the reliability was calculated for in-class anxiety as .79 and for out-of-class .81 and for the combined scales .88. Thus, reliability indices in both cases indicated that the SLSAS is a reliable instrument. As an indicator of validity, factor analysis presented in the results section also yielded a similar structure with that of Woodrow.
\end{abstract}

\title{
Data Collection and Data Analysis
}

Data were collected at the end of the spring semester of 2017-2018 school year during class time. Initial data were collected from 379 volunteer students from four schools. Before administering the survey, students were told that the participation was on volunteer basis, and they can stop responding to the survey items at any time. After data cleaning, some students supplied the same answer such as " 1 " for all questions, responses of 25 students were removed. The pages including the adapted SLSAS items were given to the teachers. They described to students that the survey was for research purposes to develop education. Students were not given any course bonus points for participating in the survey. The data were collected from university students via an online Google Survey.

To compare students' anxiety in Turkish and English, separate data were collected from 52 high school students. A typical item asked to these students was as follows: Speaking informally to my Turkish/English teacher out of class $\left(2^{\text {nd }}\right.$ item). In other words, each student in this group scored the SLSAS for both Turkish and English.

Initially, some descriptive statistics were carried out on item bases and on the group (gender, school type) bases. Then, correlational analysis was conducted between anxiety and variables: the number of years of learning Turkish, age and Turkish course grade. Next, a 2x2 MANOVA was performed to search the effect of gender and school type on in-class and out-ofclass anxieties. Finally, a repeated measure ANOVA was performed for students' in-class and out of class anxiety for both speaking Turkish and English.

\section{Research Results}

Initial descriptive statistics were conducted in order to disclose the item average scores on each level of the SLSAS for each gender, and school type.

On the item bases: Table 2 shows participants' anxiety levels about learning Turkish as a second language represented by the percent of students who endorsed each possible answer (1 to 5); items are listed in order of mean score. Responses for 1 and 2 were grouped together because they both represent non-anxious conditions. Responses for 4 and 5 were grouped together because they both represent anxious conditions. The level of anxiety can be categorized as: high - $70 \%$ or more; moderate - $40-70 \%$; and low - below $40 \%$. The average of all the items revealed that students have low anxiety in speaking Turkish as a second language. 
Table 2. Mean and standard deviations of SLSAS's items.

\begin{tabular}{|c|c|c|c|c|}
\hline Items & Mean $(S D)$ & $\begin{array}{l}1 \& 2 \\
(\%)\end{array}$ & $3(\%)$ & $\begin{array}{l}4 \& 5 \\
(\%)\end{array}$ \\
\hline 7. Talking to administrative staff of my language school in Turkish. & $2.40(1.17)$ & 59.21 & 23.8 & 17.00 \\
\hline 12 A native speaker I do not know asks me questions. & $2.29(1.28)$ & 64.12 & 17.51 & 18.36 \\
\hline 4. Taking part in a role-play or dialogue in front of my class. & $2.25(1.26)$ & 67.99 & 13.6 & 18.41 \\
\hline 5. Giving an oral presentation to the rest of the class. & $2.25(1.21)$ & 65.54 & 17.23 & 17.23 \\
\hline 6. When asked to contribute to a formal discussion in class. & $2.25(1.13)$ & 63.84 & 21.47 & 14.69 \\
\hline $\begin{array}{l}\text { 8. Taking part in a conversation out of class with more than one native } \\
\text { speaker of Turkish. }\end{array}$ & $2.11(1.14)$ & 67.51 & 19.21 & 13.28 \\
\hline 2. Speaking informally to my Turkish teacher out of class. & $2.10(1.22)$ & 68.27 & 17.28 & 14.45 \\
\hline 1. The teacher asks me a question in Turkish in class. & $2.05(1.21)$ & 75.14 & 10.17 & 14.69 \\
\hline $\begin{array}{l}\text { 9. Starting a conversation out of class with a friend or colleague who is } \\
\text { a native speaker of Turkish. }\end{array}$ & $2.03(1.17)$ & 69.77 & 18.36 & 11.86 \\
\hline $\begin{array}{l}\text { 10. A native speaker of Turkish asks me a question in Turkish out of } \\
\text { class. }\end{array}$ & $2.00(1.13)$ & 72.88 & 14.97 & 12.15 \\
\hline 11. Asking for advice in Turkish from a teacher in your school. & $1.95(1.20)$ & 74.86 & 12.99 & 12.15 \\
\hline 3. Taking part in a group discussion in class. & $1.90(1.19)$ & 73.73 & 13.28 & 12.99 \\
\hline
\end{tabular}

On the item basis, the average scores ranged from 1.90 (item 3) to 2.40 (item 7). The seventh item referring to "talking to administrative staff of my language school in Turkish" was rated highest $(M=2.40)$ and the third item referring to "Taking part in a group discussion in class" was scored the lowest $(M=1.90)$.

Recall that first six items of SLSAS were related to in-class anxiety and last six items were about out-of-class anxiety. Thus, according to the participants the most anxious condition (Taking part in a group discussion in class) occurs in the class while the least anxious conditions (Talking to administrative staff of my language school in Turkish) occurs out of the class.

On the school type: Participants' average points on the two levels of SLSAS for each type of school are shown in Table 3. The values indicated in the parenthesis just after the names of the schools are the number of participants from each school. The average anxious levels for students from four different schools were 2.02, 2.20, 2.38, and 2.01 as seen in Table 3. The mean overall scores were 2.16 on in-class anxiety, and 2.15 on out-of-class anxiety. These values indicate that participants in all schools reported slightly anxious conditions in speaking Turkish with respect to the two levels of SLSAS. Average scores of participants in SLSAS's two dimensions are approximately the same.

Table 3. Mean statistics of SLSAS's levels for each school type.

\begin{tabular}{llll}
\hline School type & $\begin{array}{l}\text { In-Class Anxiety } \\
M(S D)\end{array}$ & $\begin{array}{l}\text { Out-of-Class } \\
\text { Anxiety } \\
M(S D)\end{array}$ & $\begin{array}{l}\text { Total } \\
M(S D)\end{array}$ \\
\hline BILIM-Innovation High School for Boys (116) & $1.98(1.22)$ & $2.07(1.18)$ & $2.02(1.20)$ \\
BILIM-Innovation High School for Girls (75) & $2.27(1.25)$ & $2.12(1.22)$ & $2.20(1.23)$ \\
Suleyman Demirel College (75) & $2.40(1.26)$ & $2.36(1.28)$ & $2.38(1.27)$ \\
Suleyman Demirel University (88) & $2.00(1.03)$ & $2.02(1.05)$ & $2.01(1.04)$ \\
All (354) & $2.16(1.19)$ & $2.15(1.18)$ & $2.15(1.19)$ \\
\hline
\end{tabular}



IN THE $21^{\text {st }}$ CENTURY Vol. 76, No. 6, 2018

The average anxiety levels of all participants were 2.15 . Thus, the anxiety level for all the students corresponds to a slightly anxious degree. Among all four schools that of college students were the highest (2.40 and 2.36 for in-class and out-of-class anxieties respectively) while that of BILIM-Innovation High School for Boys students were smallest for in-class (1.98) and that of the university students were smallest for out-of-class (2.02).

Average in-class anxiety and out-of-class anxiety slightly changed according to school type while in average in both conditions, the anxiety levels were approximately the same $(2.16$ and 2.15 respectively).

On the gender: Scores for each of the two levels of SLSAS across gender groups are listed in Table 4 . The data shows that males on average $\left(M_{\text {in-class }}=2.14, M_{\text {out-of-class }}=2.16\right)$ reported more anxiety than females $\left(M_{\text {in-class }}=2.13, M_{\text {out-of-class }}=2.07\right)$.

Table 4. Descriptive statistics of SLSAS's levels for gender groups.

\begin{tabular}{llll}
\hline Gender & $\begin{array}{l}\text { In-Class Anxiety } \\
M(S D)\end{array}$ & $\begin{array}{l}\text { Out-of-Class Anxiety } \\
\boldsymbol{M}(S D)\end{array}$ & $\begin{array}{l}\text { Total } \\
\boldsymbol{M}(S D)\end{array}$ \\
\hline Female (110) & $2.13(0.84)$ & $2.07(0.79)$ & $2.10(0.86)$ \\
Male (244) & $2.14(0.85)$ & $2.16(0.88)$ & $2.15(0.89)$ \\
\hline
\end{tabular}

A Pearson product-moment correlation coefficient was calculated to evaluate the relation between the anxiety level and students' age. There was a negative insignificant relation between the variables, $r=-.068, n=354, p=.201$. Likewise, the coefficient was computed to assess the connection between the anxiety level and the duration of students' learning Turkish. There was also a negative insignificant relation between the variables, $r=-.054, n=354, p=.311$. Similarly, the coefficient was calculated to measure the relation between the anxiety level and students' course grade for Turkish language. There was also a negative insignificant relation between the variables, $r=-.001, n=354, p=.989$.

A two-way MANOVA was carried out to measure the effect of gender, and school type on students' anxiety in speaking Turkish (Table 5). Assumptions of MANOVA-normality, independence of observations, homogeneity of covariance matrices of each group, and the random and independent sampling from the population - were tested. Kolmogorov-Smirnov test result was significant in both levels of SLSAS indicating non-normal distributions. Homogeneity of covariance matrices for each group was not violated due to the insignificance of Box's M test $(p=0.13)$. Pillai's trace was utilized for the analysis of MANOVA because the normality assumption was not met, and it is more robust to violations (Tabachnick, \& Fidell, 2007).

A two-way between-subjects multivariate analysis of variance (MANOVA) was performed on the variables; gender (IV), school type (IV), in-class anxiety (DV), and out of class anxiety (DV). First of all, the effects of each independent variable on the dependent variables were analyzed by ignoring the effects of all other independent variables. MANOVA results for the main effects indicated that gender was found to have no influence on the students' overall anxiety in learning Turkish. However, a significant variance was found between the students in terms of the stages of SLSAS with regard to their school. 
Table 5. MANOVA results for gender and school type.

\begin{tabular}{llcccc}
\hline Effect & Pillai's Trace & $\boldsymbol{F}$ & $\boldsymbol{d f}$ & $\boldsymbol{p}$ & $\boldsymbol{\eta}^{2}$ \\
\hline Gender & .008 & 1.449 & $(2,348)$ & .236 & .008 \\
School & .057 & 3.416 & $(6,698)$ & .002 & .029 \\
Gender * School & .000 & & $(0,0)$ & & \\
\hline
\end{tabular}

Then, two univariate analysis of variances (ANOVA) were performed. The a level was adjusted to prevent from committing Type I error using Bonferroni's correction in which a level is divided by the number of dependent variables (Pallant, 2007). An initial level of .05 was chosen for the analysis. The adjusted alpha value for ANOVA analysis was reduced to a $=.025$ because there were two dependent variables.

As indicated in Table 6, statistically significant differences were detected in the in-class anxiety $F(3,349)=6.084, p<.05$, among school types. However, no significant difference was observed in the out-of-class anxiety $F(3,349)=2.342, p=.073$, among school type groups. Furthermore, in terms of the gender, no significant differences were observed both for in-class and out-of-class anxiety.

Table 6. ANOVA results.

\begin{tabular}{|c|c|c|c|c|c|}
\hline Source & Dependent Variable & $d f$ & $F$ & $p$ & $\eta^{2}$ \\
\hline \multirow{2}{*}{ Gender } & In-Class & 1 & 2.298 & .130 & .007 \\
\hline & Out-of-Class & 1 & .259 & .611 & .001 \\
\hline \multirow{2}{*}{ School } & In-Class & 3 & 6.084 & .000 & .050 \\
\hline & Out-of-Class & 3 & 2.342 & .073 & .020 \\
\hline \multirow{2}{*}{ Gender * School } & In-Class & 0 & . & . & .000 \\
\hline & Out-of-Class & 0 & . & . & .000 \\
\hline \multirow{2}{*}{ Error } & In-Class & 349 & & & \\
\hline & Out-of-Class & 349 & & & \\
\hline
\end{tabular}

The interaction effects were also analyzed: the dependence of effect of one independent variable on the different levels of a dependent variable. Table 6 shows that no significant influence of interaction of gender and school type on students' anxiety were found.

ANOVA results were significant for school types. Thus, Bonferroni post-hoc analysis to reveal the differences between each pair of school type (Table 7) was conducted. 
OF EDUCATION IN THE $21^{\text {st }}$ CENTURY Vol. 76, No. 6, 2018

826

Table 7. Bonferroni post hoc analysis results.

\begin{tabular}{|c|c|c|c|}
\hline \multirow[t]{2}{*}{ (I) School } & \multirow{2}{*}{$\frac{\text { (J) School }}{\text { BILIM-Innovation High School for Girls }}$} & \multicolumn{2}{|c|}{ Mean Difference $(I-J) p$} \\
\hline & & -.2863 & .123 \\
\hline \multirow{3}{*}{$\begin{array}{l}\text { BILIM-Innovation High School } \\
\text { for Boys }\end{array}$} & Suleyman Demirel College & $-.4203^{*}$ & .004 \\
\hline & Suleyman Demirel University & -.0184 & 1.000 \\
\hline & BILIM-Innovation High School for Boys & .2863 & .123 \\
\hline \multirow[t]{3}{*}{$\begin{array}{l}\text { BILIM-Innovation High School } \\
\text { for Girls }\end{array}$} & Suleyman Demirel College & -.1340 & 1.000 \\
\hline & Suleyman Demirel University & .2679 & .245 \\
\hline & BILIM-Innovation High School for Boys & $.4203^{*}$ & .004 \\
\hline \multirow[t]{3}{*}{ Suleyman Demirel College } & BILIM-Innovation High School for Girls & .1340 & 1.000 \\
\hline & Suleyman Demirel University & $.4019^{*}$ & .013 \\
\hline & BILIM-Innovation High School for Boys & .0184 & 1.000 \\
\hline \multirow[t]{2}{*}{ Suleyman Demirel University } & BILIM-Innovation High School for Girls & -.2679 & .245 \\
\hline & Suleyman Demirel College & $-.4019^{*}$ & .013 \\
\hline
\end{tabular}

As seen from Table 7, the significant differences appear between BILIM-Innovation High School for Boys and Suleyman Demirel College, and between Suleyman Demirel University and Suleyman Demirel College. In other words, college students are statistically more anxious in speaking Turkish in the class when compared to both BILIM-Innovation High School for Boys and Suleyman Demirel University students.

\section{Anxiety in Speaking Turkish versus English}

To search any differences between students' anxiety in speaking Turkish and English a one-way ANOVA was conducted. Normality checks and Levene's tests were carried out and the assumptions met. No significant differences were observed between both in-class anxiety and out-of-class anxiety (Table 8).

Table 8. ANOVA for anxiety in speaking Turkish and English.

\begin{tabular}{llllll}
\hline & Sum of Squares & df & Mean Square & $F$ & $p$ \\
\hline Between Groups & 1.298 & 3 & .433 & .895 & .444 \\
Within Groups & 199.245 & 412 & .484 & & \\
Total & 200.543 & 415 & & & \\
\hline
\end{tabular}


In performing ANOVA, four groups (two groups were in-class and out-of-class anxieties in speaking Turkish, and two groups were in-class and out-of-class anxieties in speaking English) were used. In-class and out-of-class anxiety statistics for Turkish and English languages are displayed in Table 9, and no significant differences were found with these average scores on SLSAS.

Table 9. Groups statistics for in-class and out-of-class anxieties.

\begin{tabular}{lccc}
\hline & $\boldsymbol{N}$ & $\boldsymbol{M}$ & $\mathbf{S D}$ \\
\hline In-class-Turkish & 52 & 2.19 & 0.80 \\
In-class-English & 52 & 2.20 & 0.76 \\
Out-of-class-Turkish & 52 & 2.15 & 0.60 \\
Out-of-class-English & 52 & 2.30 & 0.61 \\
\hline
\end{tabular}

As seen from Table 9, students' out-of-class anxiety was the highest in speaking English, however, this was not a significant difference. Students' in-class and out-of-class anxieties were higher for English when compared to speaking Turkish, however, this difference was also found to be non-significant.

\section{Results of the Exploratory Factor Analysis}

Initially, the factorability of the 12 SLSAS items was tested by looking at several known measures. Firstly, the Kaiser-Meyer-Olkin measure of sampling adequacy was .913, above the commonly recommended value of .6 (Pallant, 2007; Tabachnick \& Fidell, 2007), and Bartlett's test of sphericity was significant $\left(\chi^{2}(66)=1404.84, p<.00\right)$. Secondly, the diagonals of the anti-image correlation matrix were also all over .5. Finally, the communalities were above the excepted value .3 .

Twelve items relating to both in and outside the classroom anxieties were factor analyzed using principal component analysis with Varimax (orthogonal) rotation. Instead of extracting factors based on eigenvalues $>1$, two fixed numbers of factors were used because the SLSAS was two-dimensional. As hypothesized the analysis yielded two factors explaining a total of $50.79 \%$ of the variance for the entire set of variables. Item loadings on groups was in consensus with the categorization of SLSAS by Woodrow (2006). 
OF EDU

IN THE $21^{\text {st }}$ CENTURY

Vol. 76, No. 6, 2018

828

Table 10. Factor loadings and communalities of SLSAS items.

\begin{tabular}{lll}
\hline Item & Factor Loading & Communalities \\
\cline { 1 - 1 } Factor 1: In-Class Anxiety $\alpha=.787$ & & \\
\hline q4 & .816 & .680 \\
q3 & .723 & .599 \\
q5 & .623 & .452 \\
q6 & .577 & .467 \\
q1 & .561 & .417 \\
q2 & .500 & .325 \\
\hline Factor 2: Out-of-Class Anxiety $\alpha=.812$ & & \\
\hline q12 & .377 & .384 \\
q7 & .780 & .626 \\
q10 & .709 & .586 \\
q8 & .697 & .568 \\
q9 & .671 & .562 \\
q11 & .620 & .529 \\
\hline
\end{tabular}

As seen from Table 10, items are grouped according to the categorization of Woodrow (2006) who suggested first six items for in-class and next six items for the out-of-class anxiety. Factors' percentage of variances were 25.48 and 25.31 respectively. The reliability coefficients of the factors were .787 and .812 respectively. These values are within the range of acceptable reliability values in social sciences (Cortina, 1993).

\section{Discussion}

In this research, the language anxiety regarding students learning Turkish as a second language was examined with a sample from Kazakhstan. SLSAS (Woodrow, 2008) was used to determine both students in-class and out-of-class anxiety. Initial descriptive analysis was done on the item bases. Further inferential statistics were conducted on gender, school type and language (Turkish-English) variables.

The analysis of the data showed that participants' average scores on SLSAS were 2.15 out of 5, which indicates a slight anxious condition for students that learn Turkish as a second language in Kazakhstan. Similar findings were reported by Gulmez (2012), Şen and Boylu (2015), Sevim (2014), Sallabaş (2012), and Boylu and Çangal (2015). The weak anxiety can be attributed to; (1) the youth of Kazakhstan is growing up in many social activities since the early ages, (2) Kazakh and Turkish are similar and related languages, and (3) students who participate in the survey grow up in a multilingual environment. The weak anxiety state also appears in some other studies conducted out of the territory of Turkey. For instance, the research by İşcan (2011) in India showed that Turkish learners of Indian students indicated low anxious conditions.

As expected the analysis on the item bases revealed that while students were less anxious within their classmates (Taking part in a group discussion in class), they were relatively highly anxious against administrative staff (Talking to administrative staff of my language school in Turkish).

No gender differences were detected in terms of students' anxiety in speaking Turkish. 
In similar studies it has been understood that gender has no effect on FLA (Batumlu, 2006; Boylu \& Çangal, 2015; Doğan, 2008; Melanlığlu \& Demir, 2013; Sevim, 2014). In addition, no significant correlations were detected between anxiety in speaking Turkish and age, duration of learning Turkish, and Turkish course grades. The results are in consensus with the findings of Sevim (2014), and that of Melanlıoğlu and Demir (2013). In terms of duration of learning Turkish, similar results were reported by Yassin and Razak (2017).

The data were also analyzed in terms of in-class and out-of-class anxieties. While no significant differences were observed between gender groups and school type groups for the out-of-class anxiety, there was a statistically significant difference between schools for in-class anxiety. While there was no significant difference between Suleyman Demirel College students and Bilim-Innovation School for Girls students, there were statistically significant differences between Suleyman Demirel College and Suleyman Demirel University students, and between Suleyman Demirel College and Bilim-Innovation School for Boys students for in-class anxiety. To have an explanation about this finding, the ideas of college teachers were asked for the relatively high anxious results of their students. The possible reasons stated by teachers were; (1) relatively low number of Turkish course hours, (2) Turkish courses were at the end of the day, (3) many courses were replaced with social activities, (4) no Turkish courses were executed during internship training programs, and (5) students' unwillingness towards Turkish courses. The causes expressed by teachers are in agreement with the findings of Sallabaş (2012), who found that students' anxieties were related to amount of the courses that students attend.

\section{Conclusions, Limitations and Future Research}

The aim of this research was to determine participants' in-class and out-of-class Turkish language anxiety. The literature search revealed that anxiety in speaking a foreign language is widely studied, however, studying in-class and out-of-class anxiety in speaking a foreign language is a virgin area for researchers. This research can be a starting point for future researchers.

The outcomes of current research showed that anxiety in speaking Turkish is not related to students' age, gender, and duration of studying Turkish, and Turkish course grades. The only significant result was the relatively high in-class anxiety of college students. The high consensus between the findings of this research with that of previous research on anxiety in speaking Turkish, implies that future research should focus on variables other than age, gender, and course grades.

The results indicate that the SLSAS is reliable and valid and thus, it can be recommended to researchers as a new instrument to measure both in and outside classroom speaking anxiety. This is recommended because no other instruments exist to measure in-class and out-of-class anxieties.

An important result of this research is the finding that there is no significant difference between students' anxiety in learning Turkish and English. Kazakh and Turkish languages are close to each other; however, our result did not support the hypothesis that the anxiety in speaking Turkish will be less than anxiety in speaking English. Further research is needed to dissolve this finding; however, it can be attributed to students starting learning both languages at the same time and continuing in the same period.

Some restrictions to this research must be noted. Only a group of learners from private schools in Kazakhstan was searched, which is a limitation for generalizing the results. It is completely likely that further Turkish speakers in the similar or diverse learning conditions would have unlike responses.

For future research, Turkish language anxiety should be studied in different learning groups at many phases of Turkish learning with many learning objectives. It is possible that in-

$\mid$\begin{tabular}{l} 
PROBLEMS \\
OF EDUCATION \\
IN THE 21 $21^{\text {st }}$ CENTURY \\
Vol. 76, No. 6, 2018 \\
\hline 829
\end{tabular} 
Durmuş KARCI, Cemal ÖZDEMIR, Nuri BALTA. In-class and out-of-class anxiety in speaking Turkish as a second language

IN THE $21^{\text {st }}$ CENTURY Vol. 76, No. 6, 2018

830 class and out-of-class anxiety vary in many fundamental ways other than the variables surveyed here. Upcoming researches should focus on the connection of anxiety with other variables as well as its connection to students' stages of foreign language success.

\section{References}

Aydin, S., \& Zengin, B. (2008). Yabanc1 Dil Öğreniminde Kayg1: Bir Literatür Özeti [Anxiety in foreign language learning: A literature review]. Journal of Language and Linguistic Studies, 4 (1), 81-94.

Ayres, J., \& Hopf, T. (1993). Coping with speech anxiety. Norwood, NJ: Ablex Publishing Corporation.

Aiken, L. R. (1976). Update on attitudes and other affective variables in learning mathematics. Review of Educational Research, 46 (2), 293-311.

Baki, Y., \& Karakus, N. (2015). A research on speech anxiety of prospective Turkish teachers. Anthropologist, 21 (1,2), 271-276.

Baş, G. (2013). Yabancı dil öğrenme kaygısı ölçeği: Geçerlik ve güvenirlik çalışması [Foreign language learning anxiety scale: Validity and reliability study]. The Journal of Turkish Social Research, 17 (2), 49-68.

Batumlu, D. Z. U. (2006). YTÜ yabancı diller yüksek okulu hazırlı öğrencilerinin yabancı dil kaygılarının Ingilizce başarllarına etkisi [The impact foreign language anxiety on English achievements of students of YTÜ foreign language prep school]. Unpublished Master's Thesis, Yıldız Teknik University.

Bayraktar, N. (2006). Dil bilimi [Linguistics]. İstanbul: Nobel Akademi Yayıncılık.

Boylu, E., \& Başar, U. (2016). Türkçe öğretim merkezlerininin güncel durumu ve standartlaştırılması üzerine [On the current situation and standardization of Turkish teaching centers]. Akademik Sosyal Araştırmalar Dergisi, 4 (24), 309-324

Boylu, E., \& Çangal, Ö. (2015). Yabancı dil olarak Türkçe öğrenen Bosna-Hersekli öğrencilerin konuşma kaygılarının çeşitli değişkenler açısından incelenmesi [Examination of speech anxieties of Bosnian- Herzegovinian learners who learn Turkish as a foreign language in terms of some variables]. International Journal of Turkish Literature Culture Education, 4 (1), 349-368.

Breakey, L. K. (2005). Fear of public speaking-the role of the SLP. Seminars in Speech and Language, $26(2), 107-117$.

Cortina, J. M. (1993). What is coefficient alpha? An examination of theory and applications. Journal of Applied Psychology, 78 (1), 98.

Cattell, R. B., \& Scheier, I. H. (1960). Stimuli related to stress, neuroticism, excitation, and anxiety response patterns. Journal of Abnormal and Social Psychology, 60 (2), 195-204.

Ehrman, M., \& Oxford, R. (1990). Adult language learning styles and strategies in an intensive training setting. The Modern Language Journal, 74 (3), 311-327.

Daley, S. E., Hammen, C., Burge, D., Davila, J., Paley, B., \& Lindberg, N., et al. (1997). Predictors of the generation of episodic stress: A longitudinal study of late adolescent women. Journal of Abnormal Psychology, 106, 251-259.

Demir, C. E., Balci, A., \& Akkok, F. (2000). The role of Turkish schools in the educational system and social transformation of Central Asian countries: the case of Turkmenistan and Kyrgyzstan. Central Asian Survey, 19 (1), 141-155.

Doğan, A. (2008). Lise öğrencilerinin İngilizce öğrenimlerini etkileyen yabancı dil kaygısı [The foreign language anxiety that affect high school students' English language learning]. Language Journal,139, 48-67.

Dörnyei, Z. (2005). The psychology of the language learner, individual differences in second language acquisition. London, Lawrence Erlbaum Associates.

Gardner, R. C. (1985). Social psychological and second language learning: The roles of attitudes and motivation. London: Edward Arnold.

Gardner, R. C., Moorcroft, R., \& Maclntyre, P. D. (1987). The role of anxiety in second language performance of language dropouts (Research Bulletin No. 657) London: University of Western Ontario. 
Gardner, R. C. (1985). Social psychology and second language learning: The role of attitudes and motivation. London: Edward Arnold.

He, D. (2017). How to cope with foreign language speaking anxiety effectively? The case of university students in China. Electronic Journal of Foreign Language Teaching, 14 (2), 159-174.

Huang, H. W. (2004). The relationship between learning motivation and speaking anxiety among EFL non-English major freshmen in Taiwan. Unpublished master's thesis, Chaoyang University of Technology. Taichung City, Taiwan.

Horwitz, E. K., Horwitz, M. B., \& Cope, J. (1986). Foreign language classroom anxiety. Modern Language Journal, 70 (2), 125 - 132.

Horwitz, E. K. (2001). Language anxiety and achievement. Annual Review of Applied Linguistics, 21, 112-126.

Horwitz, E. K., \& Young, D. J. (1991). Language anxiety: From theory and research to classroom implications. Englewood Cliffs, NJ: Prentice Hall.

İşcan, A. (2011). The effect of language learning anxiety on the learner of Turkish as a second language: The case of Jawaharlal Nehru University, India. Educational Research and Reviews, 6 (8), 586-591.

Gardner, R. C., \& Maclntyre, P. D. (1993). A students' contributions to second language learning. Part II: Affective variables. Language Teaching, 26 (1), 1-11.

Gardner, R. C., Moorcroft, R., \& Maclntyre, P. D. (1987). The role of anxiety in second language performance of language dropouts (Research Bulletin No. 657) London: University of Western Ontario.

Gulmez, R. (2012). Foreign language anxiety on the learner of French as a third language in Turkey. Theory and Practice in Language Studies, 2 (5), 887.

Karakuş, N. (2015). Okul öncesi döneme hitap eden tema içerikli çizgi filmlerin değerler eğitimine katkısı yönünden değerlendirilmesi (Niloya örneği) [Assessment of the contribution of cartoons with themes to value education in pre-school teaching (Niloya example)]. Journal of Value Education, $13(30), 251-277$.

Liu, H. J. (2012). Understanding EFL undergraduate anxiety in relation to motivation, autonomy, and language proficiency. Electronic Journal of Foreign Language Teaching, 9 (1), 123-139.

Liu, H. J., \& Cheng, S. H. (2014). Assessing language anxiety in EFL students with varying degrees of motivation. Electronic Journal of Foreign Language Teaching, 11 (2), 285-299.

Maclntrye, P. D., \& Gardner, R. C. (1991). Methods and results in the study of foreign language anxiety: A review of literature. Language Learning, 41, 283-305.

Macintyre, P. D., Mackinnon, S. P., \& Clément, R. (2009). Embracing affective ambivalence: A research agenda for understanding the interdependent processes of language anxiety and motivation. In P. Cheng and J. X. Yan (Eds.), Cultural identity and language anxiety (pp. 1-30). Guilin: Guangxi Normal University.

Melanlığlu, D., \& Demir, T. (2013). Türkçe öğrenen yabancılar için konuşma kaygısı ölçeğinin Türkçe formunun geçerlik ve güvenirlik çalışması [Validity and reliability study of the Turkish form of speech anxiety scale for foreigners learning Turkish]. International Journal of Social Science, 6 (3), 389-404.

Mert, E. L. (2015). Türkçe öğretmen adaylarının konuşma kaygılarına ilişkin bir inceleme [A study on the speech anxiety of Turkish teacher candidates]. The Journal of International Social Research, 8 (37), 784-789.

Öner, G., \& Gedikoğlu, T. (2007). Ortaöğretim öğrencilerinin ingilizce öğrenimlerini etkileyen yabanc1 dil kaygisı [Foreign language anxiety efecting English learning of secondary school students]. Gaziantep University Journal of Social Sciences, 6 (2), 67-78.

Özkan, E., \& Kinay, İ. (2015). Öğretmen adaylarının konuşma kaygılarının incelenmesi (Ziya Gökalp Ĕ̌gitim Fakültesi Örneği) [Investigation of teacher candidates' speaking anxiety (Ziya Gökalp Education Faculty Example)]. International Journal of Turkish Literature Culture Education, 4 (3), 1290-1301.

Pallant, J. (2007). SPSS survival manual. Open University Press: New York. USA.

Pappamihiel, N. E. (2002). English as a second language students and English language anxiety: Issues in the mainstream classroom. Research in the Teaching of English, 36 (3), 327-355. 


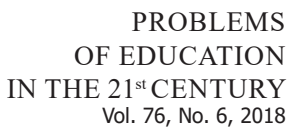

Pong, K. (2010), Learners' anxieties on posting their own speeches on Youtube.com: Facilitative or Debilitative? In selected papers from the Third Conference on College English. Colleğe English: Issues and Trends, 3, 73-100.

Sallabaş, M. E. (2012). Türkçeyi yabancı dil olarak öğrenenlerin konuşma kaygılarının değerlendirilmesi [Evaluation of speaking anxieties of learners of Turkish as a foreign language]. Turkish Studies International Periodical For The Languages, Literature and History of Turkish or Turkic, 7 (3), 2199-2218.

Sevim, O. (2012). Öğretmen adaylarına yönelik konuşma kaygısı ölçeği: Bir geçerlik ve güvenirlik çalışması [Speech anxiety scale for teacher candidates: A validity and reliability study]. Turkish Studies - International Periodical for the Languages, Literature and History of Turkish or Turkic, 7 (2), 927-937.

Sevim, O. (2014). Yabanci uyruklu öğrencilerin Türkçe konuşma kaygilarinin bazi değişkenler açisindan incelenmesi [Analysis of foreign language learners' anxiety in speaking Turkish in terms of some variables]. Ekev Academi Journal, 60 (60), 389-402.

Sevim, O., \& Gedik, M. (2014). Ortä̈ğretim öğrencilerinin konuşma kaygllarının çeşitli değişkenler açısından incelenmesi [Examination of secondary students' speech concerns in terms of various variables]. A. Ü. Türkiyat Araştırmaları Enstitüsü Dergisi [TAED], 52, 379-393.

Scovel, T. (1978). The effect of affect on foreign language learning: A review of the anxiety. Research Language Learning, 28 (1), 129-142.

Scovel, T. (1991). The effect of affect on foreign language learning: A review of the anxiety research. In E. K. Horwitz and D. J. Young, Language Anxiety: From Theory and research to Classroom Implications, Prentice Hall, Englewood Cliffs, New Jersey.

Spielberger, C. D. (1966). Theory and research on anxiety. Anxiety and behavior. New York: Academic press.

Şahin, M. (2008). Güvenlik bilimleri fakültesinde öğrenim gören yabancı ögrrencilerin Türkçe öğrenirken karşılaştıkları zorluklar [The Difficulties of foreign students in the school of security sciences in learning Turkish]. Unpublished Master's Thesis, Gazi University, Ankara, Turkey.

Şen, Ü. (2017). Türkçe öğretmeni adaylarinin konuşma kaygilarinin değerlendirilmesi [Assessment of Turkish teacher candidates' speech anxiety]. Uluslararası Türkoloji Araştırmaları ve Incelemeleri Dergisi, 2 (2), 70-84.

Şen, Ü., \& Boylu, E. (2015). Türkçeyi yabancı dil olarak öğrenen Iranlı öğrencilerin konuşma kaygılarının değerlendirilmesi [Evaluation of speech anxiety of Iranian students learning Turkish as a foreign language]. Mustafa Kemal University Journal of Social Sciences Institute, 12 (30), 13-25.

Tabachnick, B. G., \& Fidell, L. S. (2007). Using multivariate statistics (5th edn). Boston: Pearson Education.

Gregersen, T., \& Horwitz, E. K. (2002). Language learning and perfectionism: Anxious and non-anxious language learners' reactions to their own oral performance. The Modern Language Journal, 86 (4), 562-570.

Turumbetova, J. (2013). Kazakistan'daki üniversitelerde Türkçe öğretiminde karşılaşılan sorunlar [Problems encountered in teaching Turkish language in universities in Kazakhstan]. In A. Balaban and B. Çağlayan (Ed.), 2. Uluslararası Dil ve Edebiyat Çalışmaları Konferansı "Balkanlarda Türkçe [2nd International Conference on Language and Literature "Turkish in the Balkans"] (pp. 190-195). Tirana, Albania: Hëna e Plotë “Beder” University.

Williams, K. E., \& Andrade, M. R. (2008). Foreign language learning anxiety in Japanese EFL university classes: Causes, coping, and locus of control. Electronic Journal of Foreign Language Teaching, 5 (2), 181-191.

Woodrow, L. (2006). Anxiety and speaking English as a second language. RELC Journal, 37 (3), 308328.

Yassin, A. A., \& Razak, N. A. (2017). Investigating the relationship between foreign language anxiety in the four skills and year of study among Yemeni university EFL learners. 3L: Language, Linguistics, Literature, 23 (3), 147-159.

Yoğurtçu, K., \& Yoğurtçu, G. (2013). Yabancı dil olarak Türkçenin öğreniminde kaygının akademik başartya etkisi [Influence of anxiety on academic achievement in teaching Turkish as a foreign language]. Adiyaman University Journal of Social Sciences, Special Issue on Teaching Turkish, $6(11), 1115-1158$. 
Durmuş KARCI, Cemal ÖZDEMIR, Nuri BALTA. In-class and out-of-class anxiety in speaking Turkish as a second language

PROBLEMS

OF EDUCATION

IN THE $21^{\text {st }}$ CENTURY

Vol. 76, No. 6, 2018

Zorlu, K. (2008). Türk Okulları [Turkish schools]. Yeniçăg Gazetesi. Istanbul, Turkey.

833

Received: June 25, 2018

Accepted: September 22, 2018

Durmuş Karci

PhD Student, International Burch University, Sarajevo, Bosnia and Herzegovina.

E-mail: dkarci44@hotmail.com

Cemal Özdemir Assistant Professor, Suleyman Demirel University, Kaskelen, Almaty, Kazakhstan.

E-mail: cemal.ozdemir@sdu.edu.kz

Nuri Balta $\quad$ Professor, University of International Business, Abay Ave. No: 35/37 KB: 41, 050000

Almaty, Kazakhstan.

E-mail: baltanuri@gmail.com 